\title{
The Leadership Role of the Principal in Improving the Performance of Elementary School Teachers
}

\author{
Maryani $\left.{ }^{*}\right)$, Happy Fitria ${ }^{2}$, Alfroki Martha ${ }^{2}$
}

\author{
${ }^{1}$ SDN Karang Jaya \\ ${ }^{2}$ Universitas PGRI Palembang \\ *Corresponding author. Email: maryani.sdn38@gmail.com
}

\begin{abstract}
This study aims to determine and describe the role of principal leadership in improving the performance of teachers at SDN Karang Raja, Prabumulih City. The data for this study were sourced from interviews with the principal and teachers. Data collection techniques: (1) interviews, (2) observation, (3) documentation. Research data analysis techniques: (1) data reduction, (2) data presentation, (3) data verification/conclusion. The results of this study show that as an educator the principal has played a role in fostering teachers, as a manager who can manage the school, as an administration capable of arranging school work programs, as a supervisor who can carry out supervision programs, as a leader able to influence his subordinates, as an innovator capable of implementing the latest policies.
\end{abstract}

Keywords: Principal, Teacher Performance, Elementary School

\section{INTRODUCTION}

The role of the school principal is to provide learning facilities, provide guidance for the growth of teacher positions, and other professional support to become a separate strength for teachers to carry out their professional duties [1]. The principal as the leader in the school has a big responsibility to fulfill the expectations of the various parties involved, according to the role and duties of the principal, namely as a leader, manager, educator, administrator, innovator, supervisor, and motivator.

The role of leadership is a consistent pattern of behavior that the leader applies through others, namely through the behavior that the leader shows when influencing others, as perceived by others. The role is not a matter of how the leadership thinks about their behavior in leading but how other people's perceptions, especially their colleagues, about the behavior of their leaders [2].

To maintain and improve employee performance, a leader who uses his role in carrying out his duties and has the personal ability is also able to read the conditions of his subordinates and their work environment. In this case, the maturity of subordinates is directly related to the right leadership to be applied so that the principal gets adequate obedience or influence [3].

As confirmed regarding the leadership role of the principal, and the expectations that a school wants to achieve, teacher professionalism is the key that must be worked on. Teacher professionalism is the work of teachers that is reflected in designing teaching programs or planning teaching, teaching implementation, interpersonal relationships, and evaluating learning outcomes [4].

Performance is an activity carried out by each individual to achieve the goals that have been planned. Performance is the result of work that can be achieved by a person or group of people in an organization, by their respective authorities and responsibilities, to legally achieve the goals of the organization concerned, does not violate the law and by morals or ethics [5].

Teacher performance can be seen and measured based on predetermined work standards or competencies, explaining that teacher performance standards are related to the quality of teachers in carrying out their duties, as follows: (1) working with individual students, (2) preparation and planning of learning, (3) utilization of instructional media, (4) involving students in various learning experiences, and (5) active leadership from the teacher. 
Furthermore, teacher performance is carrying out the learning process both in the classroom and outside the classroom in addition to doing other activities, such as working on school administration and learning administration, implementing guidance and services to students, and implementing appraisal [6].

Furthermoreadds that teaching means continuing and developing science and technology. Meanwhile, training means developing the skills needed by the community in solving the various problems faced by society.

Relevant previous research is a reference for researchers to conduct research and strengthen allegations such as research conducted by Fitria [7] which examines the effect of teacher professional competence on teacher performance with a count of 3.015 and a table of $1.987,3$ ) there is an effect of academic supervision and professional competence of teachers on teacher performance with a value of the count of 64.652 and a value of table of 3.10. Furthermore, there is research by Lian [8] which states impose that there are similarities and differences made by previous researchers with current research, namely both examining school principals and teacher performance. Whereas the difference between previous research and current research is that it lies in the object used as the source of research data and the place of research.

Based on the background stated above, the problem is found "The learning process that should have led to learning Curriculum 13 has not been fully implemented. Because all this time, there are still teachers who use KTSP ". Due Existing studies in the study are too broad and so as not to deviate, this research is limited to the problem only "This research is limited to the study of the role of principal leadership related to efforts to improve the performance of teachers at SDN Karang Raja, Prabumulih City". So that later this research has a purpose "to know and describe the leadership role of school principals in improving the performance of teachers at SDN Karang Raja, Prabumulih City.

With this research, it can be used to 1) For the principal, the results of this study are expected to provide input on the importance of the role of the principal as the leader of formal educational institutions to improve teacher performance. 2) For teachers, as input to improve professionalism in carrying out their duties as a teacher, by providing the best for schools through the quality of work carried out. 3) For the Education Office, this research is expected to provide input to the world of education, so that they always hold training and seminars for teachers in Prabumulih. 4) For researchers, as a material to add insight to improve performance as a teacher in delivering learning to students.

\section{METHODS}

This research was conducted at SDN 38 Prabumulih, which is located in Karang Raja Village, East Prabumulih District, Prabumulih City in the 2020/201 school year. The time of the research was carried out for 3 (three) months, which is estimated to be from October 2020 to December 2020. This study used a qualitative descriptive method and data on analysis with explanations, such as observations, documentation, using deductive and inductive thinking. Qualitative data analysis used three stages: 1) data reduction, 2) display or presentation of data, and 3) conclusions and data verification.

\section{RESULTS AND DISCUSSION}

The purpose of this research is to know and describe the leadership role of school principals in improving the performance of teachers at SDN Karang Raja in Prabumulih City. Sources of research data come from interviews with the principal and several teachers who teach at SDN Karang Raja, Prabumulih City. And getting the results of the interview with the principal, the answer was that as an educator the principal always tries to guide and direct students, for example during motorbike ceremonies, guiding teachers in carrying out teaching assignments, giving directions during meetings. Always keep abreast of educational developments, both technology, and information which is constantly being updated.

As a manager, the principal prepares a school organization program, encourages teachers to work harder and the principal also tries to optimize educational facilities, such as completing learning facilities, namely children's storybooks in the library and textbooks to support student learning resources [9]. In managing teacher resources to achieve the goals of a school or institution so that teachers carry out their duties professionally. The learning process conveyed by the teacher is expected to run effectively and efficiently. The principal urges teachers to compile work programs by arranging learning devices, carrying out learning activities in a curriculum, evaluating learning outcomes [10].

Based on the results of research observations, the principal as an administrator has played a role in improving teacher performance at SDN Karang Raja, Prabumulih City. This is done by the principal when giving directions to the teacher about delivering effective and efficient learning.

Based on the results of research through interviews as a source of primary data to the principal and 6 class teachers at SDN Karang Raja, Prabumulih City, that as an educator the principal has played a role in improving teacher performance at SDN Karang Raja, Prabumulih City. This is carried out by activities carried out by the principal in character building based on the values of educators including (1) Providing understanding to students; (2) fostering teachers how to deliver effective 
and efficient learning materials; (3) Providing guidance for teachers to be able to develop the potential of these teachers in teaching, and (4) Fostering teachers to always follow developments in the field of education.

\section{CONCLUSION}

Based on the results of the research conducted, it can be concluded that the role of the Principal as Administrator, Supervisor, Leader, Innovator, Motivator, Entrepreneur, managing resources to achieve institutional goals effectively and efficiently includes: (1) Ability to compile programs; (2) Ability to organize school organizations; (3) Ability to move teachers; and (4) Ability to optimize educational facilities.

Researchers provide input in the form of suggestions to the parties: 1) The principal, through the given role, can provide the best for improving teacher performance. 2) Teachers, should always improve their abilities and add insight into technology, and be able to improve performance in teaching. 3) The Education Office, should always provide direction and guidance for schools in Prabumulih City, especially Public SDs in Prabumulih City by re-holding KKG activities, holding seminars so that teacher performance can be improved

\section{REFERENCES}

[1] Rivayanti., Arafat, Y., \& Puspita, Y. (2020). Manajemen Kepemimpinan Kepala Sekolah dalam Pembinaan Profesionalisme Guru. Journal of Innovation in Teaching and Instructional Media, 1(1), 10-17. Retrieved from https://ejournal.karinosseff.org/index.php/jitim/arti cle/view/25

[2] Mulyadi. (2014). Principal management and leadership. Jakarta: Bumi Aksara.

[3] Hendarman., \& Rohanim. (2018). Principal as Manager of Theory and Practice. Bandung: Youth Rosdakarya.

[4] Damayani, T., Arafat, Y., \& Eddy, S. (2020). Pengaruh Kepemimpinan Kepala Sekolah dan Motivasi Kerja terhadap Kinerja. Journal of Innovation in Teaching and Instructional Media, 1(1), 46-57. Retrieved from https://ejournal.karinosseff.org/index.php/jitim/arti cle/view/29

[5] Mulyasa. (2013). The Role of Principal Leadership (A Strategy To Improve Education Quality). Jakarta: Rineka Cipta.

[6] Rusyan. (2016). Teacher Performance Improvement Management. Strategy Concept and Implementation. Bandung: Youth Rosdakarya.
[7] Fitria, H. (2020). The Effect of Academic Supervision and Teacher Professional Competence on Teacher Performance in Public High Schools in Tanjung Raja District. Journal of Educational Management, Volume 9 Number 1, June 2020. Pages 103-114. ISSN. 2303-2952, e-ISSN 2622 8491 .

[8] Lian, B. (2020). The Effect of Principal Leadership Style and School Organizational Culture on Teacher Performance. Journal of Innovation in Teaching and Instructional Media Volume 1 Number 1, September 2020 Pages: 18-25.

[9] Samsudin. (2016). Leadership and Organizational Behavior. Jakarta: Raja Grafindo Persada.

[10] Suharsaputra, U. (2018). Educational Supervision (Performance Based Systems Approach). Bandung: Refika Aditama. 